\title{
Correspondence
}

Correspondents are asked to be brief.

\begin{tabular}{|c|c|}
\hline $\begin{array}{l}\text { Allegations of Negligence } \\
\text { J. Camp, M.A............ }\end{array}$ & $\begin{array}{l}\text { iving it up with Concorde } \\
\text { K. G. Heymann, M.B. } \ldots \ldots \ldots \ldots \ldots\end{array}$ \\
\hline $\begin{array}{l}\text { Muscular Dystrophy in Young Girls } \\
\text { D. Gardner-Medwin, M.R.C.P........ }\end{array}$ & $\begin{array}{l}\text { Recovery from Overdose with Glibenclamide } \\
\text { P. Kullavanijaya, M.R.C.P. } \ldots \ldots \ldots \ldots \ldots \ldots 5\end{array}$ \\
\hline $\begin{array}{l}\text { Trimethoprim-sulphamethoxazole in } \\
\text { Typhoid } \\
\text { A.C. B. Wicks, M.B., and T. V. Stamps, } \\
\text { M.B., D.P.H.................... }\end{array}$ & 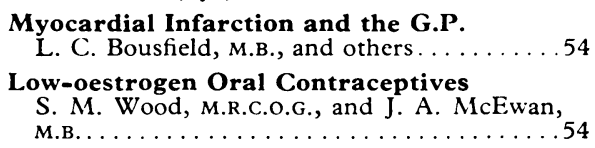 \\
\hline $\begin{array}{l}\text { s of Biological Detergents } \\
\ldots \ldots \ldots \ldots \ldots \ldots \ldots \ldots \ldots 52\end{array}$ & $\begin{array}{l}\text { Reaction to } \\
\text { G. D. Hart }\end{array}$ \\
\hline 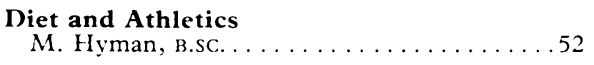 & $\begin{array}{l}\text { Tetrabenz } \\
\text { C.. A. Sou }\end{array}$ \\
\hline $\begin{array}{l}\text { Potassium an } \\
\text { H. Yatzidis, }\end{array}$ & $\begin{array}{l}\text { Benign In } \\
\text { A.S. Bl }\end{array}$ \\
\hline $\begin{array}{l}\text { Ethics of Research and the Developing } \\
\text { Countries } \\
\text { A. Talerman, M.D. } \ldots \ldots \ldots \ldots \ldots \ldots \ldots \ldots \ldots 53\end{array}$ & $\mathbf{M a}$ \\
\hline 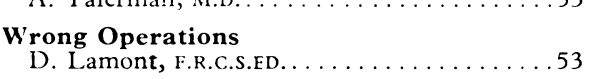 & $\begin{array}{l}\text { S. L. Barley, M.B., and H. A. Ri } \\
\text { F.R.c.o.G. } \ldots \ldots \ldots \ldots \ldots \ldots\end{array}$ \\
\hline
\end{tabular}

Postoperative Leg Vein Thrombosis

L. R. J. De Jode, F.R.C.S., and others . . . . 56

Antibiotic Therapy and Gut Flora

J. C. Gould, F.R.C.P.ED., and A. J. Keay,

Profile Analysis

W. G. Irwin, M.D., and D. W'. Neill,

F.R.C.PATH..... 56

Beta-blockade

K. Fowler, M.B.

G.P. Hospital Beds

S. A. P. Jenkins, M.B. . . . . . . . . .57

Compulsory Postgraduate Sessions

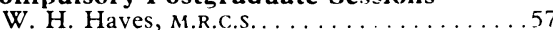

Pay of Hospital Doctors

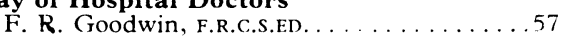

Research Funds Guide

H. G. Miller, F.R.C.P.

\section{Allegations of Negligence}

SIR,-Correspondence in the British Medical fournal during the last months of 1968 revealed concern about the incidence of allegations of negligence against doctors in Britain (30 November, p. 576; 7 December, p. 643; 21 December, p. 770 and 28 December, p. 834). With the permission and co-operation of the Medical Protection Society Ltd. I carried out a preliminary investigation to elicit some facts about the subject. A larger research project is now being planned, but it may be of interest to report the principal conclusions of the first investigation. These conclusions are based on the records of the Medical Protection Society for the years 1963-8 inclusive and concern doctors in England and Wales only. The assumption that the medical membership of the Society is a random cross-section of the medical profession in England and Wales has been made for statistical purposes.

(1) There was no significant increase in the annual number of allegations of negligence made against doctors during the period studied.

(2) Hospital doctors are five to six times as likely to have allegations of negligence

\section{Muscular Dystrophy in Young Girls}

SIR,-Your leading article (27 June, p. 745) is a welcome reflection of the light shone into a dark corner of the genetics of muscle disease by the paper of Penn and colleagues. ${ }^{1}$ Occasional autosomal recessive inheritance of Duchenne muscular dystrophy has been so difficult to prove or disprove that it has become a myth which has not been seriously challenged until now.

At the Newcastle General Hospital in a 4-year period 106 cases of muscular dystrophy have been examined. All had symptoms beginning before the age of 12 years, with equal or greater weakness of the legs than the arms, no myotonia, clear-cut progression, and made against them as general practitioners.

(3) $64 \%$ of the allegations of negligence made against general practitioners and $46^{\circ}$ of those made against hospital doctors had an outcome which was favourable to the doctor. This difference was significant $(\mathrm{P}=0.05)$.

(4) The proportion of hospital doctors in any grade corresponds closely with the proportion of allegations of negligence made against doctors in that grade. There is thus no reason to suppose that consultants, for example, are more likely to be threatened with legal action than junior staff.

(5) Doctors working in surgical and allied specialties (including anaesthetics and obstetrics) are approximately four times as likely to have allegations of negligence made against them as physicians and allied specialists.

(6) Only four out of every 100 allegations of negligence reported to the Society resulted in court action; nine out of 10 court cases were won by the doctor.-I am, etc.,

\section{Jesus College.
Oxford.}

biopsy evidence of muscular dystrophy in at least one member of the kindred. There were 52 males with pedigrees suggesting $\mathrm{X}$ linked inheritance (group I), 47 males with only affected brothers or no affected relatives (group II), two males with milder muscular dystrophy never diagnosed as the Duchenne type (group III), and five females (group IV). The age at the onset of the disease was from birth to 7 years in all the males (median of 3 years in group I) and between 2 and 9 years in the females. The boys in groups I and II were unable to walk by 15 years except for two isolated cases who walked until age 18 . They died before the age of 24 except for one isolated case aged 36 . The girls were all alive at 17 and 24-28 years of age respectively and were ambulant at the age of 17 and 26 in two cases and until 12,23, and 24 years in three others. The muscle weakness was similar in distribution in both sexes, but milder in degree in the females. Only one female had a raised serum creatine kinase level (208 i.u. at age 23), which contrasts strikingly with the high levels in males at the equivalent stages of the disease. The muscle biopsies in the females showed less fibre loss, necrosis, and regeneration than in the males. $Q$ waves and abnormal $R / S$ ratios in lead $V_{1}$ of the E.C.G. were absent in all the females whereas every male in groups I and II over 10 years of age who was tested showed one or other (and almost always both) of these features. Apart from the points mentioned there was no discernible difference between males in groups I and II. Those in group III more closely resembled the females in the clinical and pathological features. Two of the girls were sisters whose mildly affected brother had died in an accident. One adopted female's family history was unknown. The others and the boys in group III had no affected relatives; their parents were all unrelated.

It is tempting to equate groups I and II with the $\mathrm{X}$-linked Duchenne disease and groups III and IV with a clinically distinct and probably autosomal recessive disease. On the basis of this study and the Philadelphia one, such a conclusion seems to be justified. If so the autosomal disease is not only perceptibly milder than the Duchenne type but is rare in relation to its mimics. The prevalence figures for the Newcastle Regional Hospital Board area (based on cases resident in September 1969) are Duchnene muscular dystrophy $2 \cdot 8 / 10^{5}$, autosomal recessive muscular dystrophy $0 \cdot 06 / 10^{5}$, and benign spinal muscular atrophy (with onset before age 12) $0 \cdot 8 / 10^{5}$. Any autosomal cases which are indistinguishable from the Duchenne type must be even rarer if they exist at all.

There are several important consequences 
of being able to distinguish autosomal recessive cases. We need no longer be quite so cautious about genetic heterogeneity in giving genetic counsel, in evaluating methods of carrier detection, in investigating the mechanism, or in attempting the treatment of the disease. A minor consequence is that we may now assume that all mothers of isolated cases who are not carriers of the $\mathrm{X}$-linked gene are ipso facto the mothers of new mutants. By proportional studies of the rate of detection of such mothers and of known carriers by serum creatine kinase estimation, together with a count of the incidence of isolated cases in the population, it is possible to make a relatively direct estimate of the mutation rate. In the North of England it is about $10.5 \times 10^{-5}$ per gene per generation ${ }^{2}$ - a very high figure, which is, however, confirmed by the use of $\mathrm{Hal}$ dane's classical indirect method.-I am, etc.,

\section{David GardNER-MEdWIN.}

\section{Department of Neurology, \\ Massachusetts General Hospital, \\ REFERENCES \\ 1 Penn, A. S., Lisak, R. P., and Rowland, L. P., 2 Gardner-Medwin, D., Fournal of Medical Genetics, 1970 , in press.}

\section{Trimethoprim-sulphamethoxazole in Typhoid}

SIR,-We read with interest your leading article and three articles on the treatment of typhoid fever and the carrier state with trimethoprim-sulphamethoxazole (8 August, pp. 297, 318, 320, and 323).

We have just completed an uncontrolled clinical trial of trimethoprim-sulphamethoxazole in 50 cases of typhoid fever which was started in October 1969 and ended in June 1970. The diagnosis was confirmed by isolation of Salmonella typhi. Although our results are similar to the findings reported, two of our cases failed to respond to treatment. One of these was a 16-year-old African male admitted in a semicomatose and dehydrated state. He was treated for three days but on the third day had a severe melaena and died. The other was a 36-year-old African female who had five days of treatment for a pyrexia of unknown origin which responded and she was discharged home on no treatment. One week later she was readmitted seriously ill, when the diagnosis of typhoid fever was established on blood culture and trimethoprim-sulphamethoxazole therapy was re-instituted. She failed to respond and in vitro sensitivities showed that the Salmonella typhi isolated was resistant to trimethoprim-sulphamethoxazole. She had a stormy recovery subsequently on cloxacillin and chloramphenicol, and was in hospital for a total of 15 weeks owing to the development of a carrier state.

In the remaining 48 cases the temperature returned to normal in 4 days and there were no relapses, and the side effects noted were minimal. One patient inadvertently received four times the recommended twice daily dosage $(1,280 \mathrm{mg}$. of trimethoprim and $6,400 \mathrm{mg}$. of sulphamethoxazole) for two and a half days. One day later she developed jaundice, which persisted for two and a half weeks, but the aspartate transaminase
(S.G.P.T.) was only slightly elevated. Three months later at follow-up she was well and had normal liver function tests.

All our patients received three weeks' treatment, at the end of which time three rectal swabs and urines were taken for culture. No carriers were detected apart from the case reported above. The long-term follow-up is obviously most important.

Our findings agree with the previous papers on this subject that trimethoprimsulphamethoxazole is indeed a useful drug in the acute stages of typhoid fever, and it would appear hopeful that it would be just as effective in the carrier state. It is our intention to repeat this series in detail in the future.-We are, etc.,

\section{A. C. B. Wicks T. J. Stamps. \\ University College of Rhodesia Harari Central Hospital
Salisbury, Rhodesia. \\ Respiratory Effects of Biological Detergents}

SIR,-As many reports are being published in connexion with the harmful effects of so-called "biological detergents"1-3 I thought that your readers might be interested in the results of the investigations carried out by a group of doctors on the workers of a company near Venice concerned with the production of biological detergents.

A study was made of 155 randomly selected workers, the majority of whom were non-smokers.

\begin{tabular}{c|l|c}
$\begin{array}{c}\text { No. of } \\
\text { Workers }\end{array}$ & \multicolumn{1}{|c|}{ Symptoms } & $\begin{array}{c}\text { Skin Test } \\
\text { Positive }\end{array}$ \\
\hline $31 \ldots$ & None & 2 \\
$27 \ldots$ & Chronic Rhinitis & 2 \\
$52 \ldots$ & $\begin{array}{l}\text { Chronic Rhinitis } \\
\text { Hoarseness }\end{array}$ & 14 \\
$27 \ldots$ & $\begin{array}{l}\text { Persistent Dry Cough } \\
\text { Cough } \\
\text { Persistent Catarrh } \\
\text { Dypnoa of a Continuous } \\
\text { Type }\end{array}$ & 11 \\
$18 \ldots$ & Typical Asthma & 17 \\
\hline
\end{tabular}

Thus $20 \%$ only of this randomly selected group showed no symptoms involving the airways, and in $35 \%$ who had symptoms an allergy to enzymes existed. In subjects having a positive skin test, immediate positive reactions were noted, of ten severe, when making challenge tests using aerosols of extracts of enzymes, and sometimes there were delayed respiratory manifestations. In ten patients the challenge was repeated after the administration of disodium cromoglycate; this afforded complete protection, thus confirming the allergic nature of response.-I am, etc.,

EDOARDo GafFuri.

Institute of Industrial Medicine,
University of Padua, Italy.

\section{REFERENCES}

Greenberg, M., Milne, J. F., and Watt, A., British Medical fournal, 1970, 2, 629. S. J., and
Newhouse, M. L., Tagg, B., Pocock, S. J. Newhouse, M. L., Tagg, B., Pocock, S. J., and
McEwan, A. C., Lancet, 1970, 1, 689. Pepys, J., Hargreave, F. E., Longbo
and Faux, J., Lancet, 1969, 1, 1181 .

\section{Diet and Athletics}

SIR,-I read with interest your leading article on "Diet in Athletics" (15 August, p. 361 ) and would certainly agree that the diet of many athletes is greatly influenced by fads which probably have no effect on physical fitness, if one ignores the psychosomatic effect.

I should, however, like to qualify your statement that no evidence, in terms of success in athletic events, is yet available to support the work of Astrand and his colleagues. ${ }^{1}$ For some years the International Athletes' Club has been aware of the possible significance of the work of Saltin, ${ }^{2}$ Astrand, and others in terms of enhancing endurance in athletics. In May 1968 the Club organized two trial 40-kilometre races for 10 top-class walkers. In the first trial half of them prepared by following a diet similar to that recommended by Astrand, and in the second the other half did so. The trials were under the direction of Dr. L. G. Pugh of the Medical Research Council. It was found that the athletes on the high carbohydrate diet walked significantly faster over the final 10 kilometres.

These findings were passed on to the British competitors in the endurance events in the Olympic Games in Mexico in 1968. No follow-up survey has been made to find out how many athletes have adopted the diet, but outstanding individual cases are known. Dr. Ron Hill used the diet before winning the European Marathon Championship in Athens in 1969 and the Commonwealth Championship in Edinburgh this year. Dr. Michael Turner also achieved his best-ever cross-country performance this year after preparing for the International Cross-country Championships with the diet. It is also being used by competitors in longdistance fell races such as the Lake District Mountain Trial.

We are at present engaged in field trials involving measuring changes in the respiratory quotient of an athlete during a threehour run after various diets. Expired air is collected at intervals in a Douglas bag in a car driven alongside the runner. It is known that the respiratory quotient falls as glycogen reserves become exhausted. If a diet has enriched the glycogen reserves then this should postpone the drop in respiratory quotient which is, of course, accompanied by a feeling of exhaustion and an enforced slowing down.-I am. etc.,

$$
\begin{aligned}
& \text { Martin Hyman, } \\
& \text { Research Secretary. } \\
& \text { International Athlete's Club. }
\end{aligned}
$$

\section{Potassium and Chronic Renal Failure}

SIR, - With reference to the study by $\mathrm{Dr}$ G. S. Stokes and others (18 July, p. 126) we should like to present a case of refractory hypertension in a patient despite longterm low sodium haemodialysis, which successfully responded to use of a potassiumfree dialysate, suggesting a possible rele- 